\title{
Impact of Family Size and Income on "Spending -Saving" Pattern of Rural Muslim Community
}

\author{
Niyaz $^{1} \&$ Abbokar Siddiq ${ }^{2}$ \\ ${ }^{1}$ Assistant Professor, College of Management and Commerce, Srinivas University, \\ Mangalore, India. \\ ORCID: 0000-0003-4568-1658_E-Mail: niyaz0191@gmail.com \\ ${ }^{2}$ Associate Professor and Coordinator, Dept. of P. G. Studies in Commerce, University \\ College, Mangalore, India. \\ ORCID: 0000-0001-7199-7133, E-Mail: ugetsiddiq@gmail.com
}

Area/Section: Business Management.

Type of the Paper: Empirical Research.

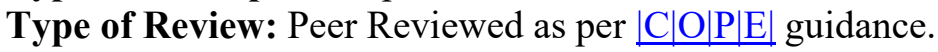

Indexed in: OpenAIRE.

DOI: http://doi.org/10.5281/zenodo.4320180

Google Scholar Citation: IJMTS.

\section{How to Cite this Paper:}

Niyaz \& Abbokar Siddiq(2020). Impact of Family Size and Income on "Spending -Saving" Pattern of Rural Muslim Community. International Journal of Management, Technology, and Social Sciences (IJMTS), 5(2), 327-335. DOI: http://doi.org/10.5281/zenodo.4320180

International Journal of Management, Technology, and Social Sciences (IJMTS) A Refereed International Journal of Srinivas University, India.

(C) With Author.

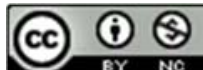

This work is licensed under a Creative Commons Attribution-Non-Commercial 4.0 International License subject to proper citation to the publication source of the work.

Disclaimer: The scholarly papers as reviewed and published by the Srinivas Publications (S.P.), India are the views and opinions of their respective authors and are not the views or opinions of the SP. The SP disclaims of any harm or loss caused due to the published content to any party.
\end{abstract}




\title{
Impact of Family Size and Income on "Spending -Saving" Pattern of Rural Muslim Community
}

\author{
Niyaz $^{1} \&$ Abbokar Siddiq ${ }^{2}$ \\ ${ }^{1}$ Assistant Professor, College of Management and Commerce, Srinivas University, \\ Mangalore, India. \\ ORCID: 0000-0003-4568-1658,E-Mail: niyaz0191@,gmail.com \\ ${ }^{2}$ Associate Professor and Coordinator, Dept. of PG Studies in Commerce, University College, \\ Hampankatta, Mangalore, India. \\ ORCID: 0000-0001-7199-7133, E-Mail: ugetsiddiq@gmail.com
}

\begin{abstract}
This study measures the association of family size and income level on spending and savings habits of rural Muslim households. A well-structured questionnaire was used to collect primary data, which was administered personally to the rural Muslim community in Dakshina Kannada district. A stratified random sampling technique was adopted and secondary data were collected from government officials. The study considered 398 rural Muslim community respondents from five taluks of Dakshina Kannada District. The study found that income and number of dependents in a family play an important role in attributing consumption and savings behavior.
\end{abstract}

Keywords: Rural Muslim, Number of Dependents, Income, Consumption Expenditure.

\section{INTRODUCTION:}

Income is necessary for consumption and savings activities of the people, but depends on family size or number of dependent in a family. Spending habit of a people is reflected through various indicators. These indicators are (i) Expenditure on food, (ii) Expenditure on health, (iii) Expenditure on education, (iv) Expenditure on clothing, (v) Expenditure on fuel and lighting, (vi) Expenditure on miscellaneous items. Economic theory tells us that saving represents the difference between income and consumption expenditure and income includes earnings from all sources during a year and is net of costs incurred in producing that income [1]. The household tends to make an adjustment to their income and expenditures to fulfill their needs during the economic crisis or recession, such as stagflation and the inflation [2]. The consumption and expenditure patterns occur due to changes in income level among households.

In India rural Muslim community is lagging behind the national average in various socio-economic indicators compared to other Socio-religious group [3] [4]. According to Gallup based on the field study particular region "Household income is a particular disadvantage for Muslims in India. Muslims (47\%) are more likely to say they find it "difficult" or "very difficult" living on their present household income than Hindus (39\%) and members of other religions (24\%) [5]. Due to employment in unorganized sector and more number of dependents has made them economically poor. Family size and income has a direct effect on consumption expenditure and saving patterns [6]. So here saving level completely depends on how much he or she will earn? Whether the income is regular? What is the pattern of utilization of income and numbers of dependents in a family? There is a lot of difference between the spending patterns of the particular community compared to the other social-religious group in India.

Many people will save money to meet any future requirements such as funds for old age, education of children, or to buy or build a house or any emergency requirements. Only a certain percentage of rural Muslim community has having the above system. Here saving can also be used for unwanted expenses like regularly buying cloth, expenses of traveling, lavish spending on food, festival, pilgrimage, wedding expenses, the payment of interest on loan from money lender and personal expenses on tobacco product and other, etc. 


\section{OBJECTIVES:}

The major objective of this research paper is: To know the difference in spending and saving level of rural Muslim community based on their income and number of dependents in a family.

\section{DATA BASE AND METHODOLOGY:}

The study is based upon both primary and secondary sources. Primary data is collected from 398 male rural Muslim community respondents from five taluks viz Belthangady, Bantval, Mangalore, Puttur and Sullia of Dakshina Kannada district, which has been selected based on proportionate stratified sampling techniques using Taro Yamane's formula. For analysis of data, exploratory data analysis techniques is used and for testing of hypothesis Chi-square Test, Fisher's Exact Test, Krushkal-Wallis Test and Tukey B- Post-hoc Test used.

\section{HYPOTHESES:}

The following four hypotheses are intended to address the objectives of this study:

H1: The spending and saving level of rural Muslim community is associated with a number of dependents in family.

$\mathrm{H} 2$ : There is a significant difference among mean rank of number of dependents with respect to spending and saving level of rural Muslim community.

H3: The spending and saving level of rural Muslim community is associated with income level.

H4: There is a significant difference among mean rank of income level with respect to spending \& saving level of rural Muslim community.

\section{RESULT AND DISCUSSION:}

\subsection{Results:}

5.1.1. The table reveals the various spending and saving levels calculated on Fisher's Exact test value and their significant association between the number of dependents in family are shown in table 1 .

Table 1: Spending and Saving Level and Number of Dependents in Family: Test Statistics of Fisher's Exact Test.

\begin{tabular}{|c|c|c|c|c|}
\hline Particular & FETV & df & Significant & Decision \\
\hline $\begin{array}{c}\text { Spending-Consumption } \\
\text { Expenditure }\end{array}$ & FETV $=135.502$ & 20 & $\mathbf{P}=\mathbf{0 . 0 0 0} * *<\mathbf{0 . 0 1}$ (Significant) & $\begin{array}{c}\text { Reject } \\
\text { H0 }\end{array}$ \\
\hline $\begin{array}{c}\text { Spending-Personal } \\
\text { Expenditure }\end{array}$ & FETV $=23.214$ & 8 & $\mathbf{P}=\mathbf{0 . 0 0 2} * *<\mathbf{0 . 0 1}$ (Significant) & $\begin{array}{c}\text { Reject } \\
\text { H0 }\end{array}$ \\
\hline Saving & FETV $=243.108$ & 20 & $\mathbf{P}=\mathbf{0 . 0 0 0} * *<\mathbf{0 . 0 1}$ (Significant) & $\begin{array}{c}\text { Reject } \\
\text { H0 }\end{array}$ \\
\hline
\end{tabular}

**Significant at $1 \%$ level of significant

From the above table it is evident that spending \& saving level of rural Muslim community is completely dependent on the number of dependents of the family as the $p$ values are less than 0.01 . Hence the null hypothesis is rejected, which leads to the conclusion that there is an association of number of dependents in the family on the spending \& saving level of rural Muslim community.

5.1.2. The table reveals the various Spending and saving level calculated on Kruskal-Wallis H Test value and their significant between the number of dependents in family are shown in table 2, Post hoc test result in table 3 and 4 with a graphical representation in figure 1 and 2.

Table 2: Kruskal-Wallis test for significant difference among mean rank of number of dependents with respect to spending \& saving level of rural Muslim community.

\begin{tabular}{|c|c|c|c|c|c|c|c|}
\hline \multirow{2}{*}{$\begin{array}{c}\text { Expenditure and } \\
\text { Saving }\end{array}$} & \multicolumn{5}{|c|}{ Number of Dependent in a Family } & \multirow{2}{*}{$\begin{array}{l}\text { Chi- } \\
\text { Square } \\
\text { Value } \\
\end{array}$} & \multirow{2}{*}{$\begin{array}{c}\mathbf{P} \\
\text { Value }\end{array}$} \\
\hline & Only 1 & $1-3$ & $3-5$ & $5-7$ & Above 7 & & \\
\hline $\begin{array}{l}\text { Consumption } \\
\text { expenditure per month } \\
\text { after availing Loan }\end{array}$ & 255.50 & 66.83 & 181.65 & 197.64 & 230.71 & 53.109 & $\mathbf{P}<0.01 * *$ \\
\hline
\end{tabular}

Niyaz, et al, (2020); www.srinivaspublication.com 


\begin{tabular}{|c|l|l|l|l|l|l|l|}
\hline $\begin{array}{c}\text { from Cooperative } \\
\text { Banks }\end{array}$ & & & & & & & \\
\hline $\begin{array}{c}\text { Personal expenses per } \\
\text { day after availing } \\
\text { Loan from } \\
\text { Cooperative Banks }\end{array}$ & 140.00 & 203.67 & 203.25 & 196.36 & 203.22 & 3.937 & $\mathrm{P}>0.05$ \\
\hline $\begin{array}{c}\text { Monthly Saving After } \\
\text { availing loans from } \\
\text { Cooperative Banks }\end{array}$ & 88.00 & 207.50 & 182.50 & 185.69 & 228.01 & 21.944 & $\mathbf{P}<\mathbf{0 . 0 1 * *}$ \\
\hline
\end{tabular}

**Significant at $1 \%$ level of significant

From Kruskal-Wallis $\mathrm{H}$ test it is clear that there is a significant difference in the consumption expenditure level and level of monthly savings of the rural Muslim families based on the number of dependents in a family at $1 \%$ level of significance as the $p$ values are less than 0.01 , So null hypothesis is rejected, but there is no significant difference in the personal expense level of the rural Muslim community based on the number of dependents, so the null hypothesis is accepted.

Table 3: Post-hoc Test between Number of Dependent in Family and Consumption Expenditure

\begin{tabular}{|c|c|c|c|c|}
\hline \multirow{4}{*}{$\begin{array}{c}\text { Consumption Expenditure (Per Month) } \\
\text { Test-hoc }\end{array}$} & Number of Dependent in a Family & $\mathbf{N}$ & $\mathbf{1}$ & \multicolumn{2}{|c|}{ Subset for alpha = 0.05 } \\
\hline \multirow{3}{*}{ Tukey } & One to Three & 24 & 1.6667 & \\
\cline { 2 - 5 } & Three to Five & 80 & & 2.7000 \\
\cline { 2 - 5 } & Five to Seven & 144 & & 2.7778 \\
\cline { 2 - 5 } & Only One & 8 & & 3.0000 \\
\cline { 2 - 5 } & Above 7 & 142 & & 3.0000 \\
\hline
\end{tabular}

From Post-hoc Comparison families with one to three dependent form one group and the rest form another group as far as consumption expenditure per month is considered.

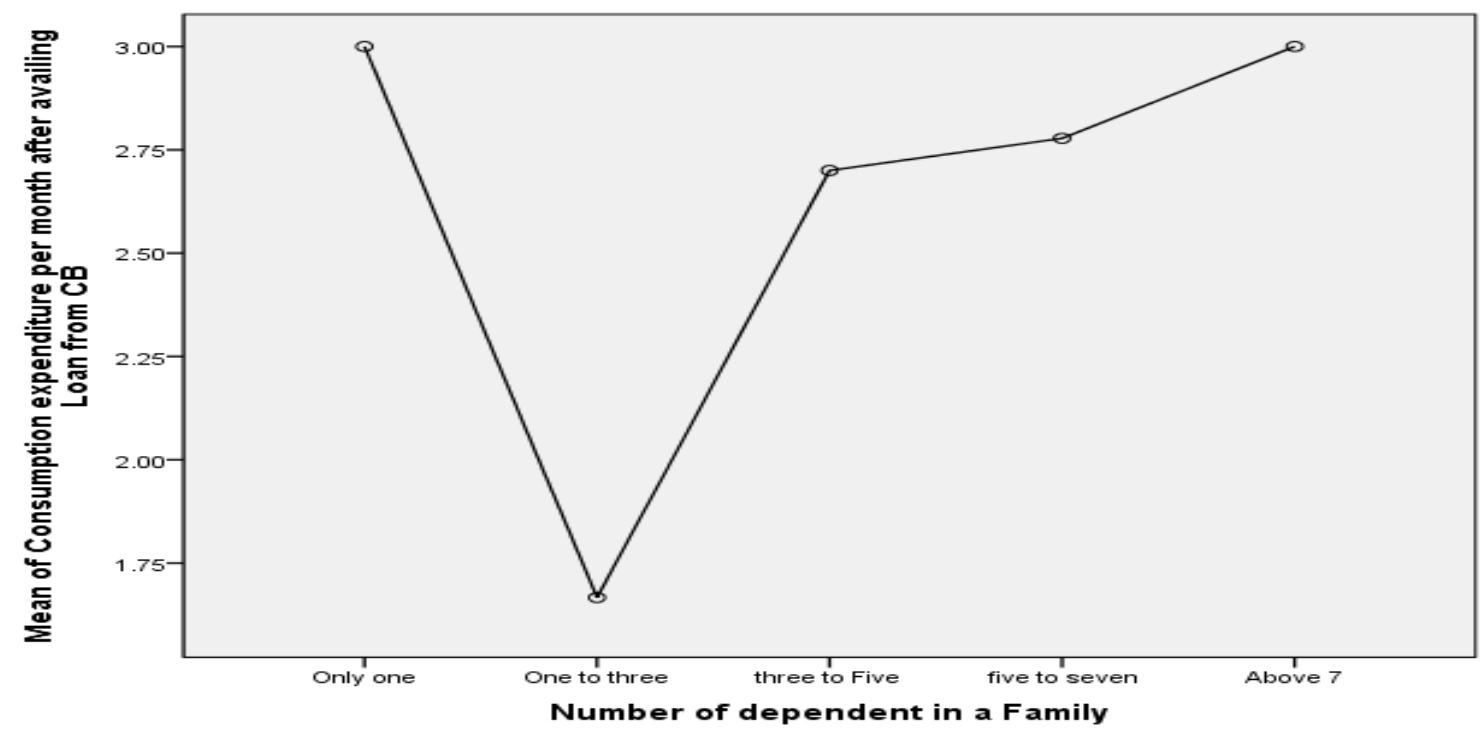

Fig. 1: Mean Consumption Expenditure and Number of Dependent in a Family 
Table 4: Post-hoc Test between Number of Dependent in a Family and Monthly Saving

\begin{tabular}{|c|c|c|c|c|}
\hline \multicolumn{4}{|c|}{ Monthly Saving } \\
\hline \multirow{2}{*}{$\begin{array}{c}\text { Post-hoc } \\
\text { Test }\end{array}$} & Number of Dependent in a Family & $\mathbf{N}$ & \multicolumn{2}{c|}{ Subset for alpha $=\mathbf{0 . 0 5}$} \\
\hline \multirow{3}{*}{ Tukey } & Only One & 8 & 2.0000 & $\mathbf{2}$ \\
\cline { 2 - 5 } & Three to Five & 80 & & 2.7000 \\
\cline { 2 - 5 } & Five to Seven & 144 & & 2.8333 \\
\cline { 2 - 5 } & One to Three & 24 & & 3.0000 \\
\cline { 2 - 5 } & Above 7 & 142 & & 3.3310 \\
\hline
\end{tabular}

As far as monthly savings considered, families with only one dependent form one group and the rest another group.

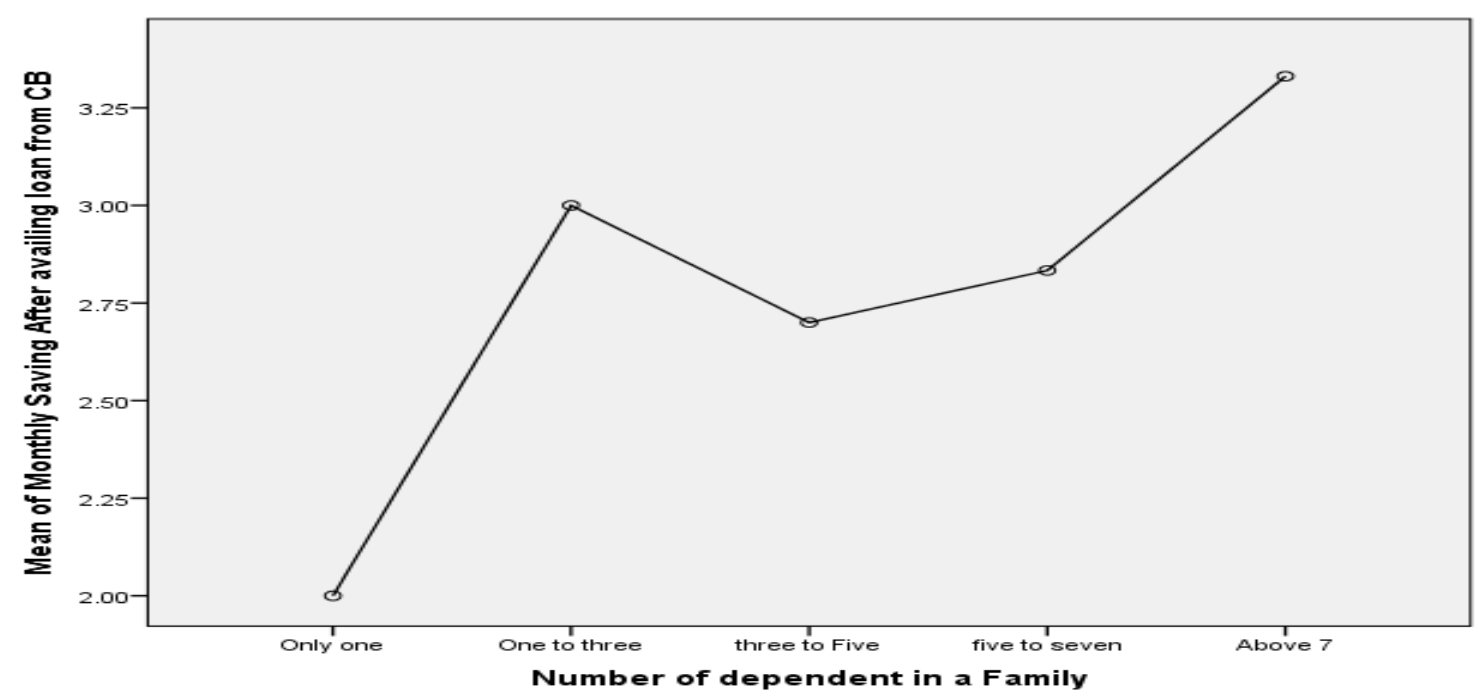

Fig. 2: Mean Monthly Saving and Number of Dependent in a Family

5.1.3. The table reveals the various Spending and saving level calculated on Fisher's exact test value and their significant association between Income level of the family are shown in table 5.

Table 5: Spending and saving level and Income level of the respondents: Test Statistics of Fisher's Exact Test

\begin{tabular}{|c|c|c|c|c|}
\hline Expenditure and Saving & FETV & df & Significant & Decision \\
\hline $\begin{array}{c}\text { Consumption expenditure per month } \\
\text { after availing Loan from Cooperative } \\
\text { Banks }\end{array}$ & FETV=527.737 & 25 & $\mathrm{P}=0.000^{* *}<0.01$ & Reject \\
(Significant) & $\mathrm{H} 0$ \\
\hline $\begin{array}{c}\text { Personal expenses per day after availing } \\
\text { Loan from Cooperative Banks }\end{array}$ & FETV=66.601 & 10 & $\mathrm{P}=0.002^{* *}<0.01$ & Reject \\
(Significant) & H0 \\
\hline $\begin{array}{c}\text { Monthly Saving After availing loan } \\
\text { from Cooperative Banks }\end{array}$ & FETV=171.898 & 25 & $\mathrm{P}=0.000^{* *}<0.01$ & Reject \\
(Significant) & H0 \\
\hline
\end{tabular}

From Fishers Exact test it can observe that spending \& saving level of rural Muslim community is dependent on the income level of the family at $1 \%$ level of significance as the $p$ values are less than 0.01 which leads to the conclusion that there is association of income level of the family on the spending \& saving level of rural Muslim community. 
5.1.4. The table reveals the various spending and saving level calculated on Kruskal-Wallis $\mathrm{H}$ test value and their significant difference between income level are shown in table 6 and Post hoc test results in table 7 and 8 with graphical representation in figure 3 and 4.

Table 6: Kruskal-Wallis test for significant difference among mean rank of income level with respect to spending \& saving level of rural Muslim community.

\begin{tabular}{|c|c|c|c|c|c|c|c|c|}
\hline \multirow{2}{*}{$\begin{array}{l}\text { Expenditure and } \\
\text { Saving }\end{array}$} & \multicolumn{6}{|c|}{ Level of Income After availing Loan from CB } & \multirow{2}{*}{$\begin{array}{r}\text { Chi- } \\
\text { Squar } \\
\text { e } \\
\text { Value }\end{array}$} & \multirow{2}{*}{$\begin{array}{c}P \\
\text { Value }\end{array}$} \\
\hline & $<10,000$ & $\begin{array}{l}10,000 \\
\text { To } \\
20,000\end{array}$ & $\begin{array}{l}\text { 20,000 } \\
\text { To } \\
\text { 30,000 }\end{array}$ & $\begin{array}{l}\text { 30,000 } \\
\text { To } \\
\text { 40,000 }\end{array}$ & \begin{tabular}{|l}
40,000 \\
To \\
50,000
\end{tabular} & $\stackrel{>}{50,000}$ & & \\
\hline $\begin{array}{l}\text { Consumption } \\
\text { expenditure per month } \\
\text { after availing Loan } \\
\text { from } \quad \text { Cooperative } \\
\text { Banks }\end{array}$ & 8.50 & 120.54 & 193.58 & 267.44 & 351.00 & 383.83 & 249.72 & $\begin{array}{r}\mathbf{P}<0.01 * \\
*\end{array}$ \\
\hline $\begin{array}{lr}\text { Personal } & \text { expenses per } \\
\text { day after availing Loan } \\
\text { from } \quad \text { Cooperative } \\
\text { Banks }\end{array}$ & 140.00 & 207.92 & 212.05 & 187.75 & 140.00 & 203.67 & 21.43 & $\begin{array}{r}\mathbf{P}<0.01 * \\
*\end{array}$ \\
\hline $\begin{array}{l}\text { Monthly Saving After } \\
\text { availing loan from } \\
\text { Cooperative Banks }\end{array}$ & 207.50 & 215.88 & 192.87 & 218.69 & 147.83 & 167.67 & 11.96 & $\mathrm{P}>0.05$ \\
\hline
\end{tabular}

** Significant at $1 \%$ level of significant

From Kruskal-Wallis $\mathrm{H}$ test it is clear that there is a significant difference in both consumption and personal expenditure level of the rural Muslim families based on the level of income at $1 \%$ level of significance as the $\mathrm{p}$ value is less than 0.01 , But there is no difference in the level of savings based on the level of income at $5 \%$ level of significance as the $p$ value is greater than 0.05 .

Table 7: Post-hoc Comparison between Level of Income and Consumption expenditure

\begin{tabular}{|c|c|c|c|c|c|c|c|c|}
\hline \multicolumn{9}{|c|}{ Consumption Expenditure (Per Month) } \\
\hline \multirow{2}{*}{$\begin{array}{l}\text { Post-hoc } \\
\text { Test }\end{array}$} & \multirow{2}{*}{$\begin{array}{l}\text { Level of Income After } \\
\text { Availing Loan from CB }\end{array}$} & \multirow[b]{2}{*}{$\mathbf{N}$} & \multicolumn{6}{|c|}{ Subset for alpha $=0.05$} \\
\hline & & & 1 & 2 & 3 & 4 & 5 & 6 \\
\hline \multirow[t]{6}{*}{ Tukey } & Less than 10000 & 16 & 1.0000 & & & & & \\
\hline & 10000 to 20000 & 104 & & 2.1538 & & & & \\
\hline & 20000 to 30000 & 167 & & & 2.6707 & & & \\
\hline & 30000 to 40000 & 64 & & & & 3.1250 & & \\
\hline & 40000 to 50000 & 23 & & & & & 4.0000 & \\
\hline & Above 50000 & 24 & & & & & & 5.3333 \\
\hline
\end{tabular}

The above table shows that, there is a significant difference in the consumption expenditure for each level of income. As income increases consumption expenditure on average has increased. 


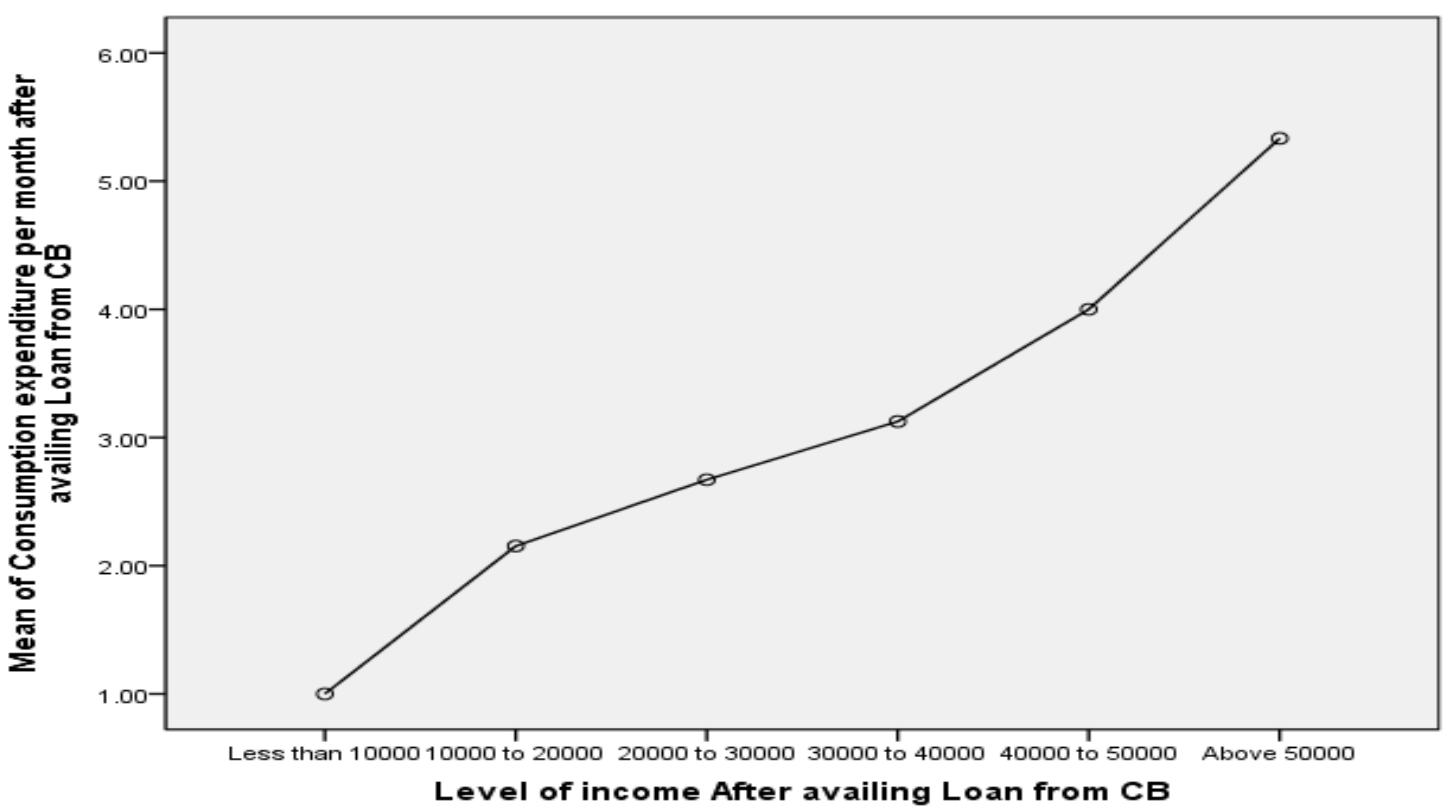

Fig. 3: Mean consumption expenditure and income level

Table 8: Post-hoc Comparison between Level of Income and Personal expenses

\begin{tabular}{|c|c|c|c|c|}
\hline \multicolumn{4}{|c|}{ Personal Expenses (Per Day) } \\
\hline $\begin{array}{c}\text { Post-hoc } \\
\text { Test }\end{array}$ & $\begin{array}{c}\text { Level of Income } \\
\text { After availing Loan from CB }\end{array}$ & $\mathbf{N}$ & \multicolumn{2}{c|}{ Subset for alpha $=\mathbf{0 . 0 5}$} \\
\hline \multirow{3}{*}{ Tukey } & Less than 10000 & 16 & 1.0000 & $\mathbf{2}$ \\
\cline { 2 - 5 } & 40000 to 50000 & 23 & 1.0000 & \\
\cline { 2 - 5 } & 30000 to 40000 & 64 & 1.2500 & \\
\cline { 2 - 5 } & Above 50000 & 24 & & 1.3333 \\
\cline { 2 - 5 } & 20000 to 30000 & 167 & & 1.3772 \\
\cline { 2 - 5 } & 10000 to 20000 & 104 & & 1.4615 \\
\hline
\end{tabular}

As far as personal expenses are considered the families with income level up less than 10, 000, 40,000 to 50,000 and 30,000 to 40,000 forms one group, and the rest of the income level form another group.

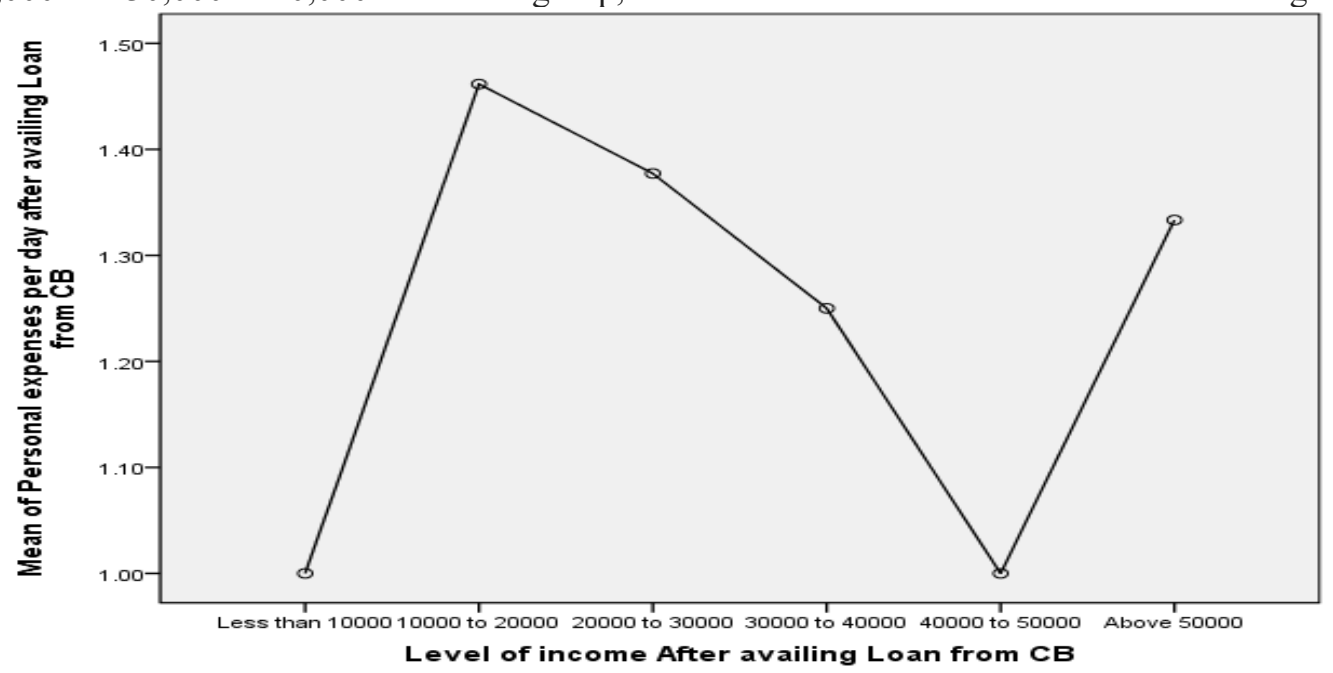

Fig. 4: Mean Personal Expenditure and Level of Income 


\subsection{Discussion:}

(1) There is a significant difference in consumption expenses and savings level among different categories of income groups based on Kruskal-Wallis H test, except for personal expenses.

(2) In case of consumption expenditure based on the post hoc test one to three dependent family member forms one group and the remaining other i.e., three to five, five to seven, only one and more than seven dependent family members forms different groups.

(3) In case of monthly savings based on post-hoc test only one dependent family member forms one group and the remaining other three to five, five to seven, one to three and more than seven dependent family members form different groups.

(4) There is a significant difference in consumption expenditure and personal expenses among different categories of income groups based on Kruskal-Wallis H test, except for saving level.

(5) In case of consumption expenditure based on the post-hoc test, there is significant difference in consumption expenditure for each level of income. As income increases, the consumption expenditure on average has increased.

(6) In case of personal expenses based on post hoc test less than $10,000,40,000$ to 50,000 and 30,000 to 40,000 income category respondents form one group and Above 50,000, 20,000 to 30,000 and 10,000 to 20,000 forms second group.

\section{CONCLUDING REMARK :}

Improving the well-being of Muslims in India begins with changing their educational and socioeconomic futures. These changes will help a systematic financial planning of any family. Spending and saving level of any community are the most important aspect of a systematic financial plan. Based on the result and discussion, the study concludes that spending \& saving level of rural Muslim community is associated with a number of dependents in family and income level.

\section{REFERENCES :}

[1] Azhar, B. A., \& Amir, M. (1995). Rural Savings: Their Magnitude, Determinants, and Mobilization. The Pakistan Development Review, 34(4), 779-788.

[2] Zurawicki, L., \& Braidot, N. (2005). Consumers during crisis: Responses from the middle class in Argentina. Journal of Business Research, 58(8), 1100-1109.

[3] Government of India (2006) Social, Economic and Educational Status of the Muslim Community of India- A Report. New Delhi: Prime Minister's High-Level Committee, Cabinet Secretariat, Government of India, New Delhi. Downloaded on 13/12/2017.

[4] Government of India. (2014). Post -Sachar Report- Socio-Economic and Educational Status of the Muslim Community in India and the Prime Minister's New 15 Point Programme. Sachar Evaluation Committee 14/173, Jamnagar House Shahjahan Road, New Delhi. Downloaded on 26/12/2017.

[5] GALLUP. Muslims in India: Confident in Democracy despite Economic and Educational Challenges, retrieved from https://news.gallup.com/poll/157079/muslims-india-confident-democracydespite-economic-educational-challenges.aspx. Downloaded on 04/07/2019.

[6] Mohammed, Z.H., Tanbir, H., \& Ohidul I.S. (2016). Impact of Remittance on Consumption and Savings Behavior in Rural Areas of Bangladesh. Journal of Business, 01(4), 25-34.

[7] Abdul, W.A. (2016). Socio-Economic Status of Deshi Muslims: A Case Study of Matia Community Development Block off Goalpara District, Assam, India. International Education \& Research Journal, 2(10), 19-21.

[8] Ahmad, I. (2007). Exploring the Status of Muslims in the Economy. Economic and Political Weekly, 42(37), 3703-3704.

[9] Akram, N., \& Akram, I.M. (2015). Savings Behaviors in Muslim and Non-Muslim Countries in Context to the Interest Rate. Pakistan Journal of Applied Economics, 25(2), 161-177.

[10] Intekhab, H. M. D. (2013). Socio-Economic and Educational Status of Muslim Women: A Comparative Outlook. Journal of Education and Practice, 14(10), 92-103. 
[11] Jabir, H., \& Falak, E. (2013). Education and Development of Muslims in India: A Comparative Study. IOSR Journal of Humanities and Social Science (IOSR-JHSS), 13(2), 80-86.

[12] Khatkar, R.K. (1987). Impact of IRDP on income, employment, and consumption expenditure on rural poor in Mahendragarh District of Haryana State. Journal of Rural Development, 6(5), 475-485.

[13] Naziruddin, A., \& Shabri, A.M. (2003). The Influence of Religiosity, Income and Consumption on Saving Behaviour: The Case of International Islamic University Malaysia (IIUM). QTISAD Journal of Islamic Economics, 4(1), 37-55.

[14] Nii, O.T., Judith, N., \& Aboagye. (2013). Selected Socio-economic Factors and their Impacts on Financial Education in Rural Communities. Journal of Economics and Sustainable Development, 4(8), 118-121.

[15] Niyaz., \& Siddiq, A. (2017). Role of Co-operative Societies in Socio Economic Development of Rural Folk-A Study with Reference to Muslim Auto Drivers in Karnataka. SJCC Management Research Review, 7(2), $163-183$.

[16] Niyaz., \& Siddiq, A. (2018). Socio-Economic Indicators for the Development of Rural Muslim Communities: A Meta-Analysis from India. International Journal of Management Studies, 5(2)3, 17 33.

[17] Reshmi, S., \& Debasis, R. (2018). Factors Affecting Gender Disparity in Muslim Education in India. Journal of Development Policy and Practice, 3(1), 87-113.

[18] Robinson, R. (2008). Religion, Socio-economic backwardness \& discrimination: the case of Indian Muslims. Indian Journal of Industrial Relations, 44(2), 194-200.

[19] Thomas, S., Sumanto, A., \& Soesilo,Y. H. (2017). Income inequality and access of housing. International Journal of Economic Research, 14(6), 53-62.

[20] Vida, M. (2008). The Changing Relationship Between Family Size and Educational Attainment Over the Course of Socioeconomic Development: Evidence From Indonesia. Demography, 45(3), 693717.

[21] Watung, S. R., \& Manado, U. N. (2018). The Influence of Financial Literacy, Social Environment Factors and Cultural Factors to Consumption Behaviour. International Journal of Scientific Research and Management (IJSRM), 6(05), 386-394.

$* * * * * * * *$ 